\title{
The Using of Casual Style in ELT For Young Learners (Sociolinguistics Perspectives)
}

\author{
Irene Debora \\ Linguistics Department Faculty Of Humanities \\ University Of Indonesia \\ E-mail: debora irene@rocketmail.com
}

\author{
Doi:10.7575/aiac.alls.v.4n.1p.124 \\ URL: http://dx.doi.org/10.7575/aiac.alls.v.4n.1p.124
}

Received: 01/12/2012

Accepted: 02/01/2013

\begin{abstract}
Young Learners have less reinforcement to speak with others. One of the causes is the trend of formal or clumsy learning setting in emphasizing the speaking proficiency. Speaking based on the culture context also contribute them in increasing their motivation to express their ideas. Casual style as one of the language variations gives contribution in increasing students' motivation to be more active in the class. The simply characteristics of Casual style can be memorized and applied easily. Casual style tends to adjust the culture of speaker in communication so it will be easy to be understood. Students also can use the utterances in their daily life because most of the utterances are familiar for them. The raising of motivation from students will give positive effect for teaching and learning process, students, and also teachers.
\end{abstract}

Keywords : Casual style, motivation, teaching and learning process

\section{Introduction}

In language production, there are some aspects that influence the using of it, such as dialect, language variation, register, and language style. As consideration when someone uses English to communicate with others, he must see the situation and condition. Based on that, English is a difficult language to learn. The context or communication situation creates language variation that can be used by the learners.

There are some definitions which are described by scholars, as expressed by Mckay dan Hornberger (1996: 151) Variation of language is the difference of language usage that considerably depending on one's regional background, social class and network, ethnicity, gender, age, and style. Besides, the meaning exposed by Hudson (1996, p. 22) in Wardaugh (2006: 25) states that language variation is a group of materials or linguistics part which has same pronunciation.

Based on the definitions, language variation can be classified in to two groups; they are Regional Variation and Social Variation (Holmes, 2008: 128) ${ }^{1}$. Regional variation refers to geographical aspect and social variation refers to social classification in communities. The classification causes the different using of language in upper, middle, and lower social class. Holmes (2008: 153) states that the way of speaking (style) is usually good indicators to know someone's background so that we can understand who are we talking with.

Liamas, Mullany dan Stockwell (2007: 95) found that style is language dimension where individual have his own words to speak with others. Someone is not always consistently uses the same words to express their opinion or feeling. Every communications will be different according to the situation that socially gives different meaning and interpretation. This case shows someone's ability to adapt with social position and how he chooses the right way to the situation given. Joss $(1961)^{2}$ explained that based on the situation the language expressed, there are five types of language styles; Frozen style, formal style, consultative style, casual style, dan intimate style. Each of these has its own definition and characteristics.

In English language teaching, the style is also can be considered as the way of teaching and communicate with students or colleagues. The different fields and students need different way of speaking in classroom. Young learners are students who need more attention in classroom because they usually felt hard in getting concentration so we need know how to speak with them. Considering their lack of language especially English words in Indonesian schools, teacher must find the easiest way to speak with them in order to make them understand the teacher's speaking. In this paper, the researcher tried to find whether teachers in some schools use this casual style especially for young learners.

\section{Discussion}

2.1 Aspects related to Socio cultural Contexts in Sociolinguistics

\footnotetext{
${ }^{1}$ In publishing 2008 Holmes states that there are two parts of language variation i.e: Regional variation dan Social Dialect

${ }^{2}$ Accessed from en.wikipedia.org./wiki/Register_(sociolinguistics) April 6 ${ }^{\text {th }} 2013$
} 
Sociolinguistics is the study of the relationship between language and society. (Holmes 2008: 1) It explains why we speak differently in different social contexts, and it is concerned with identifying the social functions of language and the ways it is used to convey social meaning. Wardhaugh (2006:13) had interpretation that sociolinguistics is concerned with investigating the relationships between language and society with the goal being a better understanding of the structure of language and how language functions in communication.

Another opinion says that it is the study of patterns and variations in language within a society or community. It focuses on the way people use language to express social class, group status, gender, or ethnicity, and it looks at how they make choices about the form of language they use (Encarta, 2005).

From the definitions above, we can conclude that sociolinguistics related to the relationship between language that is used in community and context from social function that wants to be focused on. The study analyzed the differences of language usage and the variations in many communities and its function based on the context.

2.2 Scope of Sociolinguistics

Sociolinguistic has several scopes related to situation of certain community. The scopes have characteristics and functions in communication process.

\section{Language}

Language is the way of people to communicate verbal or non verbal. Sapir (1965:78) states that Language is a purely human and non instinctive method of communicating ideas, emotions, and desires by means of a system of voluntarily produced symbols. From it, we can conclude language has very important in human's life indicated that attitude can be seen from making social relationship in social situation like conversation. The important of the relationship refers to the development a new sub- discipline called sociolinguistic. How and why the language change, when and why someone uses different language based on social, education, politic in different communities.

\section{Dialect}

Dialect is a subordinate variety of languages or regional variety of a language that has an associated literary tradition (Hudson, 1987:31). It describes the language of groups of people with common interest or jobs, or the language used in situations associated with such groups (Janet, 2001:246). If 'language' is larger than dialect, on the contrary, dialect only consists of more items from language. The function in the society usually is as a non-standard language and it has lack of prestige in the society.

\section{Mixture of Variation}

Mixture of varieties of sociolinguistics consists of some elements. Those are code switching, borrowing, pidgins, and creoles. Each of them has its own definition and function.

a. Code switching is part of variety in which a single speaker uses different varieties at different times. It takes a consequence that same speaker necessarily uses different registers on different occasions (Hudson, 1987:56).

b. Borrowing is the process of language which shows different varieties may become mixed up with each other (Hudson, 1987:58).

c. Pidgin is the process of creating a new variety out of two (or more) existing ones (Hudson, 1987:61). This process may take a number of different forms, including the creation of artificial auxiliary language.

d. Creole is a pidgin which has acquired native speakers. The process whereby a pidgin turns into a creole is called creolisation (Hudson, 1987:63).

\section{Register and Style}

The term of register has been pointed out by Wardhaugh (1992:46). He says that register is another complicated factor in any study of language varieties. Register is set of vocabulary items associated with occupationally discreet or social groups. As Halliday (1964) said in, there are three variables that determine register. They are field (the subject matter of the discourse), tenor (the participants and their relationships) and mode (the channel of communication, e.g. spoken or written).

\section{STYLE}

Style is the range of variation within the speech of an individual speaker (Bell, 1997:240). Styles are normally associated with certain groups or situations, and carry the flavor of those associations. In other words, style is variation in the speech of individual speakers which with certain groups or situations. Every person has his or her own way to express his or her meaning through a language. It expresses differently for each person.

\section{Types of Style}

Joos (1967) in his book Five Clocks (1967:153) divide the style based on the situation when the speech is uttered. The types are discussed below:

1. Frozen Style

It is a style used commonly for prose writing or for speech. It is also used when we talk to strangers. The characteristic of this style usually is the use of formal and polite language to show the identity of a speaker and to make a prose easier to understand for readers. These are some examples of frozen style:

a. Expressing our gratitude must be delivered just for Allah, God, Lord due of His kindness and helps.

b. On this occasion I desire to preach on the title ......

2. Formal Style

Formal style can be defined as a style which is used in formal situation and uses formal language. Formal style is used by people who still have a distance between them (speaker and hearer). A speaker usually avoids a repetition or another term which tends to be a casual term and used in a discussion or a meeting. Some of the examples are:

a. Mrs. Smith, would you like to have a sit first before you deliver your speech? 
b. If Mr. Andrew would be so kind ask to let me finish my words.

c. Well, it is rather difficult to say at this point.

3. Consultative Style

Consultative style is used in business or in discussing something. A Speaker who uses this style usually does not plan what he wants to say. Thus, there is a big possibility to make mistakes in speaking, such as word repetition or diction which cannot be avoided. The examples of this style:

a. Excuse me, I think it's really important for me to add about the topic that we discuss.

b. Actually, we have the same views about this problem. So, why don't you join with us?

c. I see. You will change the project and sale it to other companies, right?

4. Intimate Style

This type of style has a characteristic that its common use of personal language codes and it is only for certain group. It occurs in the certain community which has its own language style. The utterances are usually simple and representative what a speaker means. Intonation is more important than wording or grammar. The example are :

a. Tea's cold $=>$ Cold

b. Jesus Chris..! => Oh my God

c. Damn hot $=>$ Hot

5. Casual Style

The use of casual style refers to the situation in which utterances are expressed. Casual style is a style used in informal (casual) situation and using informal language. The relationship between speaker and hearer is close, so they usually use words or term repetition and frequently use ellipse sentences. It happens in conversations between parents to their children, friends, family members, etc. We can look at these examples :

(i) Do you enjoy the party? $\rightarrow$ (a) Enjoy it ?

(ii) Would you take it? $\rightarrow$ (b) Take it...

(iii) Would you give me some money ? $\rightarrow$ (c) Give me some ...

The characteristic of Casual Style

The characteristics of casual style especially in English can be explained as follows:

a. The absence of articles in the beginning of utterances for instance : Friend of mine saw it, Coffee's cold

b. The absence of subject in the beginning of utterances, for instance : Bought it yesterday ?, Makes no difference.

c. There is not auxiliary verbs used in the utterances, for instance: Leaving ?, Seen John lately?

Eggins (1997:73) states that casual conversation includes casual style which has some characteristics that makes different from the others. These characteristics show certain forms or patterns in several views. They are :

a. Most of the structures are in clauses or phrases which are grammatically divided into three types; interrogatives, declaratives, and imperative. Look at the examples:

- interrogatives :

$$
\begin{array}{ll}
\checkmark & \text { why ? } \\
\checkmark & \text { really? } \\
\checkmark & \text { what makes you say that ? }
\end{array}
$$

- declaratives :

$\checkmark \quad$ she was a selfish girl

$\checkmark$ you should know!

- $\quad$ imperative : don't be so bloody sure !

b. It usually uses swear words such as bloody, n'sync, bullshit, and others to strengthen expressions. Such as:

$\checkmark$ hey.., it's a n'sync number..!

$\checkmark$ that's bullshit..!

c. Generally, utterances consist of two constituents; a Subject and a Finite. In other words, the clauses are elapsed. We can look from the examples below :

\begin{tabular}{lll}
\hline & Full & Elliptical \\
\hline Declarative & Andra plays guitar melody & Last month \\
Imperative & Look up the girl standing up there & Look.. \\
Wh - Interrogative & When are you gonna do. Get you thesis? & When..? \\
Polar Interrogative & Uhuu...But what is it? & Do you..? \\
Exclamative & What a crap you talk, Ton! & What a crap! \\
\hline
\end{tabular}

\subsection{The using of Casual Style in ELT for Young Learners}

Teaching young learners have a different perception and way of expressing something than teaching teenagers or adults. As we know that young learners have limited attention and way to express their feeling because of undeveloped their first language. In order to their needs, teachers have to know how to communicate or make instruction in English class. 
In this case, the investigation of three Young Learner Teachers in different school was done to find out the way of teachers using casual style in class.

There are some findings that can be shown as result of questionnaire and interview of three teachers from different schools:

a. Two of the teachers were interested in teaching young learners.

b. All of them knew quite well their students in classroom because they have counseling session every month in the school.

c. Teachers saw most of the students still used simple language even they sometimes said something grammatically incorrect.

d. Teachers often simplified the instructions to make the students understood or made the process quickly because the students were not patiently waited for the instruction finished by teachers.

e. Students more understood when teachers used casual style and they can quickly responded the teachers instructions or questions.

From the interview administered, the data were taken to find out how often the teachers used the casual style and what kind of utterances that said by teachers and students in the classroom, such as:

Utterances by Students

\begin{tabular}{|l|l|}
\hline \multicolumn{1}{|c|}{ Utterances used } & \multicolumn{1}{c|}{ The formal form } \\
\hline I'm bored. & $\bullet$ This no longer interests me. \\
\hline Any homework? & $\bullet$ Do we have homework? \\
\hline this be on the test? & $\bullet$ Will this learning appear on the assessment? \\
\hline Toilet, miss? & $\bullet$ May I go to the toilet, miss? \\
\hline He/she is touching/looking at me. & $\bullet$ A classmate is disturbing my learning. \\
\hline No like, miss & $\bullet$ I don't like it, miss \\
\hline
\end{tabular}

Utterances by Teachers

\begin{tabular}{|l|l|}
\hline \multicolumn{1}{|c|}{ Utterances used } & \multicolumn{1}{c|}{ The formal form } \\
\hline $\begin{array}{l}\text { Take out your book/ } \\
\text { pencil/pen/paper. }\end{array}$ & $\bullet$ Take out the necessary learning equipment \\
\hline Stop talking & $\bullet$ Don't talk in classroom, please! \\
\hline Line up & $\bullet$ Arrange yourselves in a line. \\
\hline Use eraser & $\bullet$ Use eraser when there's mistake \\
\hline No talking when walk & $\bullet$ Don't talk when you're walking. \\
\hline
\end{tabular}

\section{Conclusion}

The ability of students in speaking is not only aroused from the materials or method in teaching speaking, but the way of language is expressed also has an essential role in it. Casual style can be both applied in teaching process and outside class activities or in daily life. Applying casual style in classroom made young learners understood the subject. Besides, students will have more motivation to study and keep focused on the material.

By giving them simple instructions and utterances, teachers will make them understand easily the meaning of the utterances. The utterances can be in the form of imperative, for example; take it!, Come forward!, or in the form of interrogative, such as; any question?. The explanation about casual style and the utterances based on the context make students easier to understand about casual style and motivate them more active to speak. As casual style is one part of language variations in English, students and teachers should give more attention to it in order to enrich the language variation and finally improve the language skills even they don't have enough words yet to express their thinking.

\section{Reference}

Bloch, B. (1960). Style and Linguistics. Jakarta: Tantular.

Eckert, Penelope and John R. Rickford. (2001). Style and Sociolinguistic Variation. Cambridge: Cambridge University Press

Eggins, S. and Slade, D. (1997). Analyzing Casual Conversation. Great Britain: Creative Print and Design Wales.

Fishman. (1972). Sociolinguistics. New Jersey: Prentice Hall, Inc.

Holmes, Janet. (2008). An Introduction to Sociolinguistics. England: Pearson Education Limited 
Liamas, Carmen, Louise Mulany, and Peter Stockwell. (2007). The Routledge companion to sociolinguistics. USA and Canada: Routledge

Mckay, Sandra Lee and Nancy Hornberger. (1996). Sociolinguistics and Language Teaching. Cambridge: Cambridge Unversity Press.

Marzano, R. J. (2001). A new era of school reform: Going where the research takes us. Aurora, CO: Mid-continent Research for Education and Learning.

Romadlon, Farid Noor. (2012). Using Casual Style to Engage Students' Speaking Motivation for English Young Learners. TEYLIN 2: From Policy to Classroom pp.39-45

Wardhaugh, Ronald. (2006). An Introduction to Sociolinguistics. Cambridge: Harmolls Ltd, Bodmin.

\section{THE QUESTIONNARE}

\section{Part I}
a. What grade are you teaching now?
b. Are you really interested in young learners?
c. How is the situation of your class?
d. Do you know your students well in the classroom?
e. What do you think of the language used by the students? Is it formal or informal?
f. Do you often simplify the language or instructions in classroom in order to make the students understand you?
g. Can your students understand your simplified instructions in classroom?

Part II

\begin{tabular}{|c|c|c|c|c|c|c|}
\hline \multirow[t]{2}{*}{ No } & & \multicolumn{5}{|c|}{ Degree of Frequency } \\
\hline & & 4 & 3 & 2 & 1 & 0 \\
\hline 1 & $\begin{array}{l}\text { you use different way of speaking for adults and } \\
\text { young learners }\end{array}$ & & & & & \\
\hline 2 & $\begin{array}{l}\text { you use simple words like what this?, where you?, } \\
\text { etc }\end{array}$ & & & & & \\
\hline 3 & $\begin{array}{l}\text { your students use simplified language like no need, } \\
\text { no like, I want, etc }\end{array}$ & & & & & \\
\hline 4 & $\begin{array}{l}\text { Your students interact with others using simple } \\
\text { language }\end{array}$ & & & & & \\
\hline 5 & $\begin{array}{l}\text { Your students tell stories or anything in their life to } \\
\text { you }\end{array}$ & & & & & \\
\hline 6 & $\begin{array}{l}\text { You find that simple language is effective used in the } \\
\text { classroom }\end{array}$ & & & & & \\
\hline
\end{tabular}

